\title{
The Theology of a Jealous God: A Study of Exodus 20:3-5 and a Jealous God
}

\author{
Brian Marpay ${ }^{1}$, Nasokhili Giawa ${ }^{2}$ \\ Sekolah Tinggi Teologi Jaffray Jakarta \\ E-mail: 1brianmarpay86@gmail.com, ${ }^{2}$ nsgiawa@gmail.com
}

\begin{abstract}
Jealousy is one of the characteristics of God, which is essential in His divinity. It's just that some take it casually and even tend to see that jealousy like this is not too severe. This is why this article was written to ascertain the extent to which God's jealousy is essential to be studied by God's people and its application from the perspective of the responsibility of faith in Him. It should be understood that the Bible shows this nature of God, that He is a jealous God. However, this jealousy of God is certainly not as heavy as humans' jealousy in general. God was jealous of the acts of disloyalty made by humans against Him, namely deliberately rebelling against and worshiping other gods. God has the right to be jealous because of the disobedience of His chosen people, who have violated the content of His eternal covenant. Therefore, this article is written using a biblical-theological approach, namely trying to understand the purpose of God's jealousy as contained in Exodus 20: 3-5 by paying attention to the text and context and then analyzing it to find its value, relevance, and application in daily life. In the end, this article shows that the background behind God's jealousy is, firstly, there is a broken promise, second is the existence of a double attitude (because of a special relationship before), and the third is that there is an attitude of relationship dissatisfaction that causes jealousy, namely adultery with other gods.
\end{abstract}

Keywords: God, Jealous, betrayed, ignored, dissatisfied.

\begin{abstract}
ABSTRAK: Sikap cemburu merupakan salah satu sifat khas Allah yang esensial dalam keilahian-Nya. Hanya saja, ada yang menanggapinya secara biasa saja bahkan cenderung melihat bahwa sifat cemburu seperti ini tidak terlalu serius. Inilah yang menyebabkan artikel ini ditulis untuk memastikan sejauh mana kecemburuan Tuhan penting dipelajari oleh umat Tuhan dan aplikasinya dari perspektif tanggung jawab iman kepada-Nya. Perlu dipahami bahwa Alkitab menunjukkan sifat Allah ini, bahwa Ia adalah Allah yang cemburu. Namun, kecemburuan Allah ini tentu tidak sama bobotnya dengan kecemburuan yang biasa dilakukan manusia pada umumnya. Sejujurnya Tuhan Allah sangat cemburu dengan tindakan ketidaksetiaan yang dibuat oleh manusia terhadap-Nya yaitu dengan sengaja memberontak dan menyembah allah lain. Allah berhak cemburu karena ketidak-taatan umat pilihan-Nya yang telah melanggar konten kovenan-Nya yang kekal. Karena itu, artikel ini ditulis menggunakan pendekatan teologi biblika yaitu berupaya memahami maksud kecemburuan Allah sebagaimana dimuat di dalam Kel. 20:3-5 dengan memperhatikan teks dan konteks lalu menganalisis untuk menemukan nilai, relevansi, dan aplikasinya dalam kehidupan sehari-hari. Pada akhirnya artikel ini memperlihatkan bahwa yang menjadi latar belakang di balik kecemburuan Allah ialah, pertama adanya janji yang diingkari, kedua ialah adanya sebuah sikap menduakan (karena adanya hubungan spesial sebelumnya), dan yang ketiga ialah adanya sikap ketidakpuasan relasi yang menimbulkan kecemburuan yaitu perzinahan dengan allah-allah lain.
\end{abstract}

Kata Kunci: Allah, cemburu, diingkari, diduakan, ketidakpuasan.

Article History: Submitted: 12 Desember 2020 Revised: 17 Februari $2021 \quad$ Published: 27 Juli 2021

\section{PENDAHULUAN}

Pembahasan tentang kecemburuan Allah telah banyak dilakukan. Hanya saja tidak mengupas secara komprehensif apa yang menjadi dasar utama sehingga Allah menjadi cemburu. Harus diakui bahwa tema tentang kecemburuan ini memunculkan ku- riositas pembaca dengan berbagai pertanyaan terutama karena berkaitan dengan sifat Allah. Apakah mungkin Allah dapat cemburu? Atas dasar apa Ia harus cemburu? Kepada siapa Ia harus cemburu? Bagaimana Ia cemburu. Bukankah Ia adalah Allah yang Mahamulia, lalu untuk apa Ia harus cemburu? Ini 
hanyalah sebagian pertanyaan yang mungkin muncul dalam pikiran dan mungkin juga masih banyak lagi pertanyaan-pertanyaan substantif yang berkembang serta mengganggu nalar para pembaca. Karena itu, melalui artikel ini, peneliti mencoba menelusuri apa sebenarnya yang menjadi latar belakang sehingga Allah cemburu? Apa yang dimaksud dengan kecemburuan Allah dalam teks dan konteks tersebut? Bagaimana memahami dan memaknai sifat Allah yang cemburu ini dalam konteks kehidupan gereja masa kini?

Merujuk pada judul di atas, peneliti berupaya membedah salah satu sifat khas Allah tersebut, sebab realitanya disebutkan bahwa Allah yang disembah adalah Allah yang cemburu. Tentu, hal ini tidak terlepas dari teks dan konteksnya. Beragam analisis-hermeneutis/eksegetikal mengemukakan pandangan yang saling melengkapi dan mempertajam gagasan tentang kecemburuan Allah dimaksud. Packer (2008) menyatakan bahwa referensi Musa tentang kecemburuan Allah berkaitan dengan salah satu bentuk penyembahan berhala atau yang lain. Selain pemikiran Packer, Johnson (1984) memberikan sebuah pemahaman yang menarik perihal Keluaran 20:3-5 dengan menyatakan bahwa perintah dalam ayat ini sebenarnya bersifat mencegah terjadinya perbuatan politeisme dan praktik magis. Bahwa hanya ada satu TUHAN yang tidak dapat dibandingkan dengan realitas individu maupun segala hal yang ditawarkan oleh dunia termasuk benda atau patung yang dikultuskan oleh manusia yang pada gilirannya membangkitkan kecemburuan Allah terhadap tindakan manusia (Johnson, 1984).

Senada dengan gagasan Johnson, Kusnandar (2015) memberikan sebuah pemahaman yang menarik perihal Keluaran 20:3-5 dengan menyebutkan bahwa uraian dimaksud dapat dipahami sebagai alasan Allah melarang manusia menyembah kepada patung atau sejenisnya karena patung merupakan benda mati ciptaan manusia yang menggambarkan pemahaman tentang Allah. Selain itu, pada umumnya pemujaan dan penyembahan pada zaman purba dengan menggunakan media patung bertujuan hanya untuk memuaskan keinginan mendesak dan hawa nafsu manusia yang sangat terbatas, seperti pemujaan kepada dewa kesuburan tanah yang pada akhirnya berkonotasi pada pelanggaran seks. Oleh karena itu, sebaiknya tidak berkompromi dengan segala bentuk apapun yang berkonotasi beribadah kepada patung (Kusnandar, 2015).

Pada sisi lain, tulisan ini sedang mengajak dan membawa nalar para pembaca untuk melihat salah satu sifat Allah yang esensial dari aspek keilahian-Nya, yakni kecemburuan-Nya. Memang penggunaan terminologi "kecemburuan Allah" ini sangat berhubungan dengan karakter dan sifat khas yang melekat pada manusia sehingga wajar bila mengalami kesulitan untuk memahaminya. Pada akhirnya, setelah pertanyaan-pertanyaan di atas terjawab, dapat dipastikan bahwa TUHAN dapat, dimungkinkan, dan layak untuk cemburu. Gagasan inilah yang akan dibahas dan disajikan dalam tulisan ini.

Meninjau uraian tentang pemahaman mengenai istilah cemburu seperti yang telah diuraikan di atas, maka kini timbul pertanyaan, "apakah makna cemburu seperti ini dapat dikenakan kepada TUHAN Allah"? Melihat kebenaran tentang Allah Pencemburu dari perspektif Alkitab, maka dapat dikatakan bahwa "Makna Allah Pencemburu menunjuk kepada sifat khas (attribute) TUHAN Yang Mahaadil, dan Mahasetia, yang telah mengikat Perjanjian Berkat (Covenant) dengan Israel sebagai Umat-Nya, dimana dari pihak Allah, Ia adalah Penjamian Perjanjian Berkat-Nya, yang menuntut keteritakatan, ketaatan dan kesetiaan kepada-Nya dari pihak umat-Nya". Dari pengertian ini dapat dikatakan bahwa Allah Cemburu, artinya Allah yang Mahaadil telah diperlakukan secara tidak adil oleh umat-Nya, dengan melanggar Perjanjian Berkat TUHAN. Pada sisi lain, Allah yang Mahasetia, yang menuntut ketaatan dan kesetiaan umat-Nya telah disikapi dengan ketidak taatan dan ketidak setiaan Israel. Ini adalah indikator penginkaran Israel terhadap Perjanjian Berkat Allah. Dengan demikian, jika TUHAN Allah menghukum 
Israel, maka Kemahaadilan dan Kemahasetiaan-Nya menjadi dasar bagi Tindakan penghukuman-Nya. Alasannya adalah karena Israel ternyata mengingkari Perjanjian Berkat TUHAN, dan bersikap tidak taat serta tidak setia dengan memberontak secara sengaja terhadap TUHAN Allah dan Perjanjian Berkat-Nya (Tomatala, 2003).

\section{METODE}

Riset ilmiah ini menggunakan jenis penelitian kualitatif dengan pendekatan studi teologi biblika. Untuk menyajikan konsep Allah pencemburu, peneliti melakukan pembacaan secara berulang-ulang terhadap teks Keluaran 20:3-5, kemudian peneliti melakukan analisis mendalam (analisis-hermeneutika/ eksegetikal) terhadap teks tersebut. Selain itu, peneliti juga melakukan studi pustaka terhadap buku-buku teologi yang memiliki keterkaitan langsung, yang pada gilirannya peneliti melakukan sintesis terhadap topik ini, antara lain tulisan Berkhof (1993), Tomatala (2003), Barnabas Ludji (2009), Brehm (1992), Stamps (1996), Pfeiffer dan Harrison (1962), Idleman (2014). Dengan demikian, diharapkan kajian ini dapat menemukan gambaran yang komprehensif dan utuh terhadap konsep Allah yang cemburu sebagaimana dimuat dalam Keluaran 20:3-5.

Dalam proses penelitian ini, peneliti berupaya untuk menyuguhkan pandangan-pandangan yang alkitabiah dan dapat dipertanggungjawabkan secara ilmiah. Karena itu, ada beberapa gagasan teologis yang digali dari pandangan para teolog. Di samping itu, peneliti juga menggunakan pendekatan diskusi akademik dengan beberapa teolog dalam forumforum atau pertemuan ilmiah, diskusi dengan beberapa rekan dosen biblika dan teologi sistematika yang memiliki kualifikasi mumpuni, serta mengikuti beberapa seminar yang bersinggungan langsung dengan judul ini. Tujuan utama adalah upaya mencari titik temu dan berupaya sedapat mungkin menyampaikan gagasan teologis tentang konsep Allah pencemburu dalam konteks Keluaran 20:3-5. Dengan demikian, topik ini peneliti memaparkannya secara deskriptif sesuai dengan hasil temuan biblis. Pada akhirnya diharapkan agar artikel ini bermanfaat dan dapat diimplementasikan dalam kehidupan pribadi, bermasyarakat, dan bergereja sehingga mengenal sifat khas Allah yang cemburu tersebut secara benar yang kemudian mengenal diri sebagai umat kepunyaanNya yang khusus dan khas dibanding dengan ciptaan yang lain.

\section{HASIL DAN PEMBAHASAN}

Dari perspektif manusia, pada umumnya, kata cemburu merupakan bahasa yang sangat erat dengan sifat, karakter, dan perasaan kemanusiaan. Kadangkala kata cemburu sering digunakan pada kasus-kasus tertentu dalam mengomunikasikan perasaan yang sangat kuat dari seseorang kepada orang lain. Sifat kecemburuan ini sangat manusiawi. Kecemburuan seperti ini dijelaskan dengan makna: Pertama, merasa tidak atau kurang senang melihat orang lain beruntung dan sebagainya. Kata lain disebut sirik. Kedua, kurang percaya, curiga (karena iri hati) (Indonesia, 2014). Pengertian etimologis seperti ini memang cenderung bersifat negatif, yang tidak mungkin dilabelkan kepada TUHAN Allah. Namun, dalam memahami sifat-sifat khas Allah perlu mengerti kisi negatif yang dikandungnya. Dalam kaitan ini, Gaebelein menyatakan bahwa kata cemburu yang digunakan kepada Allah selalu paralel antara penyembahan berhala dan perzinahan (Gaebelein, Harris, \& Kaiser Jr., 1990, p. 486). Mengingat karena berkaitan langsung dengan penyembahan berhala dan perzinahan, Surbakti (2009) menggambarkan bahwa cemburu ialah sebuah perasaan yang timbul karena ingin memiliki sendiri pasangannya dan perasaan terancam karena kehadiran orang lain dalam hubungannya. Saat mengalami rasa cemburu biasanya sistem rasionalnya tidak bekerja sebagaimana mestinya (Surbakti, 2009). Ada dua unsur yang ditegaskan oleh Surbakti bahwa cemburu itu berkaitan dengan adanya "ancaman" dan juga timbulnya gangguan pada "sistem rasionalitas". 
Pendapat yang hampir sama datang dari Brehm (1992), yang berpendapat bahwa cemburu adalah emosi yang dialami ketika seseorang merasa hubungan dengan pasangan terancam dan mengakibatkan hilangnya kepemilikan, biasanya ini akan timbul apabila ada pihak ketiga dalam hubungan tersebut (Brehm, 1992). Pandangan Brehm lebih diperjelas bahwa ancaman tersebut karena adanya pihak ketiga. Pandangan Duma (2009) juga tidak jauh berbeda dengan gagasan Surbakti (2009) dan Brehm (1992) yang menyatakan bahwa cemburu merupakan reaksi yang terjadi pada hubungan romantis yang sedang terancam oleh pihak ketiga, dimana ancaman ini bersifat subjektif dan nyata. Hal ini biasanya diikuti dengan rasa takut kehilangan pasangan (Duma, 2009).

Jadi dari perspektif manusia, berdasarkan gagasan yang telah dikemukakan dapat disimpulkan bahwa cemburu ialah suatu keadaan normal yang terjadi dalam hidup manusia secara khusus berkaitan dengan emosi, dimana ada dorongan atau reaksi dari luar dirinya, berupa perasaan terancam yang dikarenakan adanya orang ketiga atau karena faktor lain seperti iri hati, yang dapat mengakibatkan hilangnya kepemilikan. Ini sangat berhubungan dengan perasaan seseorang yang dapat berpotensi kehilangan akal sehat.

\section{Pemahaman Cemburu dari Konteks Teks Alkitab}

Kitab Keluaran merupakan salah satu kitab yang sangat penting karena mengandung nilai historis berkenaan dengan perjalanan panjang bangsa Israel. Tidak hanya mengandung nilai historis, tetapi juga mengandung nilai teologis yang kemudian memperjelas kemahakuasaan Allah dalam kisah sejarah itu. Berkenaan dengan pentingnya peristiwa Keluaran, Ludji (2009) menyatakan,

Peristiwa keluaran yang merupakan inti iman Israel dapat diketahui dari kesaksian Alkitab. Menurut kesaksian Alkitab, peristiwa keluaran merupakan keajaiban tangan Allah. Sedangkan bagi orang Mesir, peristiwa itu hanyalah pelarian sekelompok budak dari Mesir.
Perlu dipahami dengan baik bahwa Keluaran 20:1-17 berkenaan tentang perintah TUHAN yang ditujukanNya kepada bangsa Israel melalui perantaraan nabi Musa kala itu, yang kemudian dikenal dengan Kese-

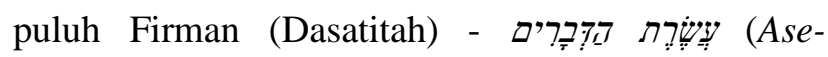
ret Hadevârïm), yang merupakan Covenant TUHAN Allah dengan Israel sebagai Umat-Nya. Dasatitah yang merupakan Perjanjian Berkat TUHAN dengan umat-Nya dimulai dengan pernyataan, Akulah TUHAN Allahmu, yang membawa engkau keluar dari tanah Mesir, dari tempat perbudakan (Kel. 20:2). Kebenaran ini menegaskan tentang Allah sebagai Penjamin Perjanjian-Nya yang mengharuskan Israel menaati, dan berlaku setia terhadap TUHAN dan Perjanjian Berkat-Nya (Tomatala, 2003).

Teks Keluaran 20:3-5 sebagai pokok kajian utama dari topik penelitian ini, berhubungan dengan misi Perjanjian TUHAN dengan umat-Nya, sebagai Hukum Pertama, atau Stipulasi Pertama (First Stipulation) yang berunyi, "Jangan ada padamu allah lain di hadapan-Ku”. Dalam Terjemahan Baru (TB), Lembaga Alkitab Indonesia menerjemahkan teks, sebagai berikut:

Ayat 3. Jangan ada padamu allah lain di hadapan-Ku.

Ayat 4. Jangan membuat bagimu patung yang menyerupai apa pun yang ada di langit di atas, atau yang ada di bumi di bawah, atau yang ada di dalam air di bawah bumi.

Ayat 5. Jangan sujud menyembah kepadanya atau beribadah kepadanya, sebab Aku, TUHAN, Allahmu, adalah Allah yang cemburu, yang membalaskan kesalahan bapa kepada anak-anaknya, kepada keturunan yang ketiga dan keempat dari orang-orang yang membenci Aku.

Dalam konteks teks ini terutama pada ayat 3, TUHAN mengajak umat-Nya Israel, agar tidak menyembah allah lain selain Allah yang hidup yang telah menyaksikan perbuatan-perbuatan ajaib yang pernah dilakukan-Nya. Namun pada sisi lain, pada ayat 5 dapat ditemukan salah satu sifat TUHAN yang dengan gamblang dinyatakan oleh TUHAN Allah secara personal bahwa Ia adalah Allah yang Mahaadil 
dan Mahasetia, sehingga cemburu menjelaskan tentang hukuman-Nya terhadap ketidaktaatan dan ketidaksetiaan Israel terhadap Perjanjian-Nya.

Meninjau uraian sebelumnya, dapat dilihat bahwa Alkitab mencatat tentang manusia yang secara umum dan Israel secara khusus, telah menunjukkan sikap ketidaktaatan dan ketidaktundukan terhadap TUHAN dan Kovenan-Nya, bahkan jauh sebelum pemberian Kesepuluh Hukum tersebut sebagai Kovenan Musa atau Mosaic Covenant (Tomatala, 2003). Perlu diketahui bahwa sebelum umat Israel keluar dari tanah Mesir pun, sebenarnya TUHAN Allah telah menunjukkan identitas-Nya sebagai Allah yang tidak kompromi dengan perbuatan jahat manusia, khususnya Israel. Hal ini terindikasi dari sikap ketidaksukaan Allah atas tindakan-tindakan yang dibuat Israel yang bertentangan dengan titah-Nya. Tentu, hal ini menjadi indikator yang paling utama, bahwa Israel degan sendirinya telah terhukum, karena melanggar Perjanjian Berkat TUHAN.

Sebagai contoh, zaman Nuh dan air bah yang berlanjut sampai kepada keluarnya bangsa Israel dari tanah perbudakan - Mesir, kemudian perjalanan mereka mengelilingi padang gurun di bawah pimpinan nabi Musa yang selalu diwarnai dengan berbagai persungutan dan bahkan berpalingnya mereka kepada penyembahan berhala buatan tangan mereka sendiri. Pengalaman mereka di gurun Sin memperlihatkan kualitas kehidupan bangsa Israel yang masih hidup dalam persungutan bahkan mempertanyakan siapa dan di mana Allah berada (Kel. 16). Jadi, Sangatlah beralasan jika Allah menyatakan dengan tegas bahwa "Jangan ada padamu allah lain di hadapan-Ku" sebagai prinsip pertama dari Kesepuluh Firman yang disampaikan-Nya melalui Musa. Kemudian berlanjut dengan munculnya kecemburuan Allah atas tindakan ketidaksetiaan manusia tersebut sebagaimana dijelaskan pada ayat 4-5 sebagai alasan utama mengapa Allah begitu cemburu.

Seperti diketahui bahwa perintah 1-4 dalam Kesepuluh Hukum (Dasatitah) membicarakan relasi vertikal antara TUHAN dengan manusia, sedangkan perintah 5-10 merupakan relasi horizontal antara manusia dengan sesamanya. Melalui Kesepuluh Hukum (Dasatitah) ini, manusia dapat membangun relasi yang baik dengan TUHAN dan relasi yang baik dengan sesamanya. Memang dalam Perjanjian Lama, banyak kisah-kisah dari bangsa Israel yang menggambarkan dan menunjukkan ketidaksetiaan mereka tersebut, yang pada gilirannya mempertegas gambaran mengenai sifat Allah yang cemburu terhadap Israel (konteks Perjanjian Lama) dan manusia sebagai ciptaan-Nya (secara umum) yang beridentitas mulia dan berharga di mata-Nya.

Sehubungan dengan posisi Torah, Bambang Budijanto dalam bukunya, TORAH - Dalam Hidup Bangsa Israel menyatakan bahwa pemunculan yang konsisten dari pola ungkapan ini, yaitu kaitan antara pelanggaran terhadap perjanjian kudus dengan kalimat pertama Dasatitah, membuktikan bahwa "Jangan ada padamu allah lain di hadapan-Ku" adalah inti dari ketetapan-ketetapan atau kewajiban-kewajiban yang dibuat di Gunung Sinai yang sekaligus mendeskripsikan ketidaksetiaan bangsa Israel. (Budijanto, 1995)

\section{Teks Keluaran 20:3-5}

Untuk memahami gagasan tentang Teks Kel. 20:3-5 sebagai bagian dari Kovenan TUHAN dengan Israel, dan implikasinya untuk mengerti sikap TUHAN Allah Yang Mahaadil dan Mahasetia, yang dilukiskan secara antromorfistik sebagai cemburu dan disebut Pencemburu dalam penelitian ini, maka teks ini dieksegesis sebagaimana dipaparkan pada bagian berikut.

\section{Keluaran 20:3}

Dalam teks Ibrani (WTT Leningrad Hebrew Old Testament), ayat 3 ini berbunyi, sebagai berikut:

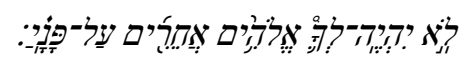
Pada awal kalimat dari ayat ini, telah dimulai dengan penggunaan kata "jangan/ not" - "lo - ל" "ל " Diikuti dengan penggunaan kata "allah" dalam kon-

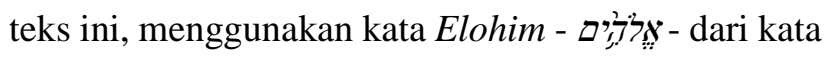


dasar אֶֶ - Eloha - any god, bentuk noun common masculine plural absolute - kata benda, maskulin, jamak. Jika diartikan ke dalam bahasa Indonesia bisa berarti "Allah" bisa juga "allah". Kemudian menyusul penggunaan kalimat "lain di hadapan-Ku" -

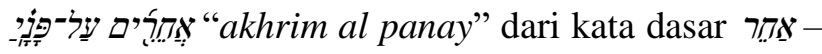
akher - (adjective masculine plural - kata sifat maskulin jamak).

\section{Keluaran 20:4}

Dalam teks Ibrani (WTT Leningrad Hebrew Old Testament), ayat 4 ini berbunyi:

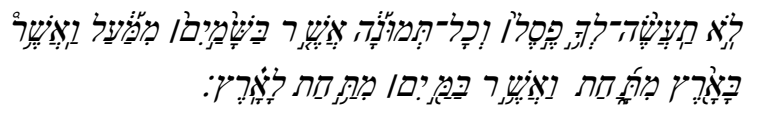

Penggunaan kata selanjutnya ialah "patung" - pesel (פְ⿱乛龰) "an idol, image - idola, gambar" berbentuk noun, masculine, singular, absolute - kata benda, maskulin, tunggal, absolut). Idol di sini menjelaskan tentang of stone, clay, wood, or metal - batu, tanah liat, kayu, atau logam yang merupakan perwujudan dari sesembahan.

Kemudian ada kata "menyerupai" meng-

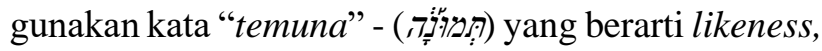
form, shape artistic, image, representation (kemiripan, bentuk, bentuk artistik, gambar, representasi). Kata "temuna" ini adalah noun, common, feminine, singular, dan absolute.

\section{Keluaran 20:5}

Dalam teks Ibrani (WTT Leningrad Hebrew Old Testament), ayat 5 ini berbunyi:

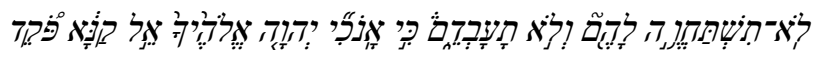

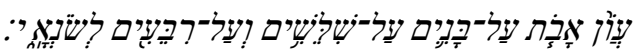

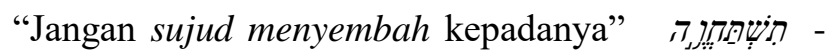
tishttakhweh - to bow down, to depress, to declare untuk membungkuk, untuk menekan, untuk menyatakan. Kata ini berasal dari kata dasar חוה khawa - bow down deeply, do obeisance - sujud dalam-dalam, lakukan ketaatan. Larangan agar tidak sujud menyembah diikuti dengan kata larangan agar

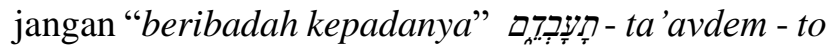
work, serve, to be tilled, to be worked, to cause, to serve, to be lead to serve - untuk bekerja, melayani, untuk digarap, untuk dikerjakan, untuk dituntun, untuk melayani, untuk memimpin melayani. Kata ini berasal dari kata dasar עָכב - avad yang berbentuk verb hophal imperfect 2 nd person masculine singular suffix $3^{\text {rd }}$ person masculine plural.

Kemudian kalimat "Allah yang cemburu",

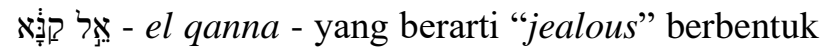
adjective, masculine, singular absolute . Konsekuensi logis dari kecemburuan Allah ini akan dapat berbuntut panjang yakni berpotensi membalaskan kesalahan bapa kepada anak-anaknya, kepada keturunan yang ketiga dan keempat dari orang-orang yang membenci Allah.

\section{Konteks Keluaran 20:3-5}

Untuk memahami teks Keluaran 20:3-5, maka sangat diperlukan adanya pemahaman tentang konteks teks Keluaran 20 ini, sebagai bagian dari Kovenan TUHAN Allah dengan Israel sebagai umatNya. Berikut ini adalah penjelasan dan penjabaran tentang apa yang sedang terjadi dalam konteks teks.

\section{Konteks Teks Keluaran 20:3}

Sesungguhnya umat Allah di Perjanjian Lama memahami dan mengetahui bahwa hanya ada satu Allah yang sejati, yang Esa dan yang patut disembah. Dalam Ulangan 6:4 menjelaskan komitmen dan konfesi yang menyatakan, "Dengarlah, hai orang Israel: TUHAN itu Allah kita, TUHAN itu esa!" Namun dalam kenyataannya pernyataan Allah dalam Ulangan 6:4 ini baru digaungkan-Nya setelah puluhan tahun lamanya pasca pemberian Kesepuluh Firman ( Aדברָרים Aseret Hadevârïm) dari Allah kepada Musa di gunung Sinai. Meskipun demikian, sepanjang sejarah bangsa Israel, mereka tetap saja terjebak ke dalam penyembahan berhala atau dengan kata lain bahwa Israel hidup dan menyembah kepada allah-allah bangsa kafir yang ada di sekitar mereka.

Keluaran 20 ayat 3 sesungguhnya merupakan penegasan khusus kepada bangsa Israel bahwa Allah sesembahan leluhur mereka adalah Allah yang Esa 
(monoteis), yang telah membebaskan mereka dari Tanah Mesir, dan mengikat Perjanjian Berkat dengan mereka. Senada dengan pandangan ini, Alkitab Penuntun Hidup Berkelimpahan juga memberikan pandangan yang sangat tegas tentang ayat 3 ini. Menurut Stamps (1996), hukum seperti ini bertujuan untuk mencegah timbulnya pemahaman dan ajaran politeisme di kalangan Israel, dan pada sisi lain, teks ini juga berisi tuntutan keras bahwa Israel hanya boleh menyembah kepada TUHAN, sebagai Allah mereka seperti diungkapkan dalam beberapa referensi (Ul. 32:39; Yos. 24:14-15). Di sisi lain, penegasan ini juga datang dari Suseno (2006) yang mengatakan bahwa hanya Yahwehlah satu-satunya TUHAN atas bangsa Israel, dan dewa-dewi lain tidak perlu, bahkan tidak boleh diperhatikan, maka bangsa Israel sampai pada satu kesimpulan bahwa hanya Yahwehlah TUHAN dan tak ada ilah lain. Israel menemukan monoteisme (Suseno, 2006). Pernyataan ini menjelaskan tentang nilai eksklusivitas relasi antara Allah dengan umat kepunyaan-Nya.

Esensi dasar dari perintah ini sesungguhnya memberikan gambaran bahwa hanya TUHAN Allah yang layak untuk disembah dan tidak membuka ruang sekecil apapun bagi penyembahan kepada allah lain, karena ini adalah pengingkaran terhadap Kovenan atau Perjanjian Berkat-Nya. Dengan kata lain, TUHAN Allah mencipta atmosfir yang sengaja didesain oleh-Nya dengan Kovenan-Nya supaya umatNya dapat dengan leluasa taat dan setia menyembah serta berbakti kepada-Nya saja, dan bukan kepada allah lain. Dengan demikian, manusia wajib menyembah Dia dan menutup rapat-rapat peluang penyembahan terhadap allah lain dalam bentuk dan wujud apa pun.

\section{Konteks Teks Keluaran 20:4}

Ayat 4 menegaskan tentang larangan untuk membuat patung yang menyerupai apa pun yang ditiru dari bentuk yang berada di langit, di bawah bumi, atau yang ada di dalam air, atau yang ada di bawah bumi. Dalam keterangan Keluaran 34:17 merangkum patung-patung ini dengan istilah sebagai allah tuangan ( ilah yang terbuat dari logam yang tidak boleh disembah atau dimuliakan.

Dalam konteks sekarang, Lestari (2015) memperlihatkan gagasan dari sudut pandang yang berbeda dengan menyebutkan realita dari berbagai lokus dan waktu serta mencoba untuk melakukan evaluasi. Lestari (2015) berpendapat bahwa pada zaman milenial seperti sekarang ini, akan kelihatan naif jika akhirnya ada yang memutuskan untuk mempercayai allah yang lain dalam berbagai bentuk apalagi banyak ilah (politeisme). Alasan utama bagi Lestari (2015) adalah zaman telah berubah dan terus berkembang dengan berbagai kemajuannya bagi peradaban dunia. Perubahan ini tentu memengaruhi sudut pandang sehingga lebih rasional. Hal yang menarik dalam konteks masa kini adalah adanya perubahan dan pergeseran paradigma orang-orang yang mengaku tak beragama pun turut berkontribusi untuk merekonstruksi kembali cara pandang mereka. Orang ateis pun sudah meninggalkan konsep mempercayai TUHAN, padahal sebelumnya mereka adalah teis yang taat. Sekalipun status mereka yang cukup masif di Eropa dan Amerika, di mana mereka diberi ruang untuk mengaktualisasikan diri pada instansi-instansi pemerintah, namun hal ini sangat kontradiksi dengan negara-negara di luar Eropa dan Amerika, di mana identitas sebagai seorang ateis pun tidak mudah untuk diterima secara sosial, terlebih lagi untuk mengungkapkannya secara terang-terangan di depan publik, yang berkonotasi destruktif (Lestari, 2015).

Konteks saat ini dan tantangannya tentu berbeda dengan konteks zaman Perjanjian Lama. Perjanjian Lama memperlihatkan ketegasan yaitu TUHAN melarang keras umat-Nya Israel, untuk membuat patung yang menyerupai TUHAN atau apapun itu, lalu sujud dan menyembah pada patung tersebut. Ironis jika akhirnya umat-Nya membuat patung lalu kemudian menyembah Allah. Namun, inilah realita dari dunia Perjanjian Lama, sebagai bukti sejarah yang sangat valid yaitu sebuah petunjuk kebobrokan 
perilaku umat Allah di Perjanjian Lama (bandingkan dengan Keluaran 32:1-35 “Anak Lembu Emas”).

Konteks ayat ini memberikan pemahaman kepada para pembaca, bahwa untuk alasan apapun dan dengan tujuan apa pun itu, sangat terlarang bagi umat-Nya Israel, untuk membuat bahkan menyembah patung yang menurut anggapan mereka itu adalah "Tuhan". Sejalan dengan Keluaran 20:4, ternyata TUHAN melalui Musa kembali mengingatkan atau menasihati mereka dalam Ulangan 4:19, 23-28 tentang konsep memelihara hukum Allah supaya mereka tidak membangkitkan kecemburuan TUHAN melalui penyembahan kepada matahari, bulan dan bintang, atau segenap tentara langit, yang kemudian mereka disesatkan untuk sujud menyembah dan beribadah kepada sekaliannya itu (Ul. 4:19).

\section{Konteks Teks Keluaran 20:5}

Klimaks dari perintah Allah ini ada pada ayat 5, bahwa Ia sangat cemburu terhadap umat-Nya, jika bangsa tersebut hidup dalam penyembahan berhala. Berkhof (1993), menyatakan bahwa gagasan atributatribut natural dan moral TUHAN yang berkaitan erat dengan keadilan dan kesetiaan-Nya sebagai sifatsifat-Nya yang natural menjelaskan berbagai prinsip yang kemudian mengkualifikasikan Allah sebagai Yang adil dan Yang setia. Hal ini menjelaskan adanya tuntutan bagi Israel untuk bersikap taat dan setia, sebagai bagian dari tanggung jawab moral yang mesti dipertanggungjawabkan (Berkhof, 1993).

Dari pandangan Berkhof di atas, dapat dipastikan bahwa kecemburuan Allah pada ayat 5 sangatlah beralasan, sebab kecemburuan Allah tersebut, merupakan bagian dari atribut-atribut natur konstitusional Allah yang asli serta melekat pada diri Allah.

\section{Implikasi dan Implementasi Teologis}

\section{Perspektif Antropomorfistik}

Perlu diketahui bahwa dalam banyak hal, baik dalam Perjanjian Lama maupun dalam Perjanjian Baru, Allah menggunakan berbagai macam cara untuk menyatakan diri, kehendak, dan karakter-Nya. Karena itu, gagasan Keluaran 20:3-5 sarat dengan antropomorfisme. Dalam agama dan mitologi Yunani, terminologi antropomorfisme merujuk pada konsep bahwa Allah memiliki bentuk seperti manusia pada umumnya yang di dalamnya memiliki struktur yang hampir sama dengan manusia yang memiliki kepribadian dan watak yang serupa walaupun tidak sama.

Dalam beberapa kasus, sering kali penggunaan kata "Ia atau Dia" merujuk pada figur laki-laki sebagai kata pengganti untuk subjek yang berkenaan dengan TUHAN. Hal ini, secara psikologis dimaksudkan agar manusia lebih memahami dan mengerti entitas yang disembah dalam arti yang sesungguhnya. Konsep dan gagasan-gagasan seperti inilah yang kurang ditegaskan oleh penulis yang lain ketika berhadapan dengan teks yang sama yang kemudian menganggap sisi antropomorfisme ini terabaikan.

Berbagai sumber menjelaskan bahwa secara khusus dalam mitologi kuno yang berasal dari kebudayaan Mesopotamia dan Yunani kuno, TUHAN sering kali dipresentasikan sebagai dewa-dewi dengan bentuk dan kepribadian seperti manusia. Kepribadian dimaksud, antara lain: ada perasaan kasih, perasaan marah, perasaan dendam, perasaan dikhianati, perasaan cemburu, perasaan benci, dll.

Ajaran Kristen melihat bahwa gagasan antropomorfisme berperan untuk membantu umat Allah memahami karakter dan sifat khas Allah sekalipun tidak memiliki fisik seperti manusia. Karena itu, konsep Allah menjadi cemburu dalam teks dan konteks Keluaran 20:3-5 merupakan bagian utuh dari cara Allah menyatakan dan mendekatkan diri-Nya kepada manusia.

\section{Perjanjian Berkat yang Diingkari}

Seperti telah dikisahkan dalam kitab Kejadian bahwa sejak TUHAN menempatkan manusia di taman Eden, Adam dan Hawa telah membuktikan ketidak-setiaan mereka pada ketetapan Allah. Pelanggaran terhadap titah Allah merupakan bagian yang tidak terpisahkan dari penyelewengan dan pelanggar- 
an yang disengaja terhadap ketetapan Allah. Hal ini memvalidasi bahwa "manusia" memiliki benih mengingkari atau menghianati perintah Allah. Pelanggaran terhadap ketetapan Allah sebagaimana dikisahkan di dalam Kejadian 3, yakni memakan buah pengetahuan yang baik dan yang jahat yang telah dilarang merupakan indikator kuat bahwa manusia, umat-Nya telah menyeleweng yaitu lebih memilih pada bisikan gombal Iblis dibandingkan dengan ketetapan Allah.

Pada ayat 3-4 dari Keluaran 20 sesungguhnya Allah telah memproyeksikan ketidaksetiaan manusia di hadapan-Nya sehingga memunculkan kalimat antisipatif. Kalimat yang menyatakan, "Jangan ada padamu allah lain di hadapan-Ku. Jangan membuat bagimu patung yang menyerupai apa pun yang ada di langit di atas, atau yang ada di bumi di bawah, atau yang ada di dalam air di bawah bumi" memberikan sebuah penegasan sekaligus peneguhan kepada umatNya, bahwa potensi atau peluang untuk tergoda dan jatuh ke dalam pelanggaran/dosa termasuk penyembahan kepada berhala sangatlah besar. Kemudian, inilah yang tidak diinginkan oleh TUHAN. Allah menjadi cemburu. Berkenaan dengan pernyataan "Jangan ada padamu allah lain di hadapan-Ku" berkaitan erat dengan eksklusivitas hubungan yang luar biasa antara Allah dan manusia, umat kepunyaanNya. Menanggapi hal ini, Darmaputera (2005) menyatakan bahwa perintah yang sepintas lalu memberi kesan mengekang dan membatasi itu, ternyata adalah perintah yang membebaskan yaitu membebaskan manusia dari ketidakpastian, karena ketiadaan pegangan. Juga membebaskan manusia dari ketertindasannya, karena memutlakkan yang tidak mutlak. Atau, karena memperilah yang bukan Allah (Darmaputera, 2005).

Memang, zaman yang semakin canggih ini membuat sulit untuk menemukan orang yang masih menghidupi bentuk penyembahan berhala apalagi membuat patung secara fisik kemudian sujud menyembah pada patung tersebut. Kalau pun hal tersebut ada, kemungkinan karena masih primitif dan hidup di daerah terpencil yang notabene masih teri- solasi karena tergolong pada zona 3T (Terdepan, Terluar, Tertinggal) dan berjarak jauh dengan kota bahkan jauh dari sentuhan IPTEK.

Akan tetapi, kemajuan ilmu pengetahuan dan teknologi seperti itu, tidak membuat manusia terhindar atau tidak bersentuhan sama sekali dengan penyembahan berhala. Justru penyembahan berhala pada zaman yang semakin maju serta modern seperti sekarang ini, secara tidak langsung memaksa kuasa Iblis bekerja dengan lebih canggih lagi, guna membawa banyak pengikutnya menuju kebinasaan. Kehadiran teknologi canggih juga dapat menjadi jembatan untuk penyembahan berhala.

Idleman (2014) memberikan gambaran baru tentang penyembahan berhala dalam zaman moderen ini. Kyle menguraikan bentuk penyembahan berhala yang hari ini dilakoni oleh manusia dan keadaan tersebut sama sekali tidak disadari oleh manusia. Idleman (2014) menguraikan bentuk penyembahan berhala tersebut sebagai berikut: allah makanan, allah seks, allah hiburan, allah kesuksesan, allah uang, allah prestasi, allah sains, dll.

Janji dikhianati atau tindakan ketidaksetiaan dapat digambarkan dalam berbagai tindakan manivestatif. Sebagai contoh dalam sebuah rumah tangga bahwa jika salah seorang dari pasangan hidup yang tidak lagi menunjukan sikap ketidaksetiaannya terhadap pasangannya, sudah bisa dipastikan adanya masalah dalam konteks pernikahan tersebut. Memang ada banyak alasan yang cukup kompleks yang melatarbelakangi sebuah gangguan relasional dalam rumah tangga hingga mengalami perceraian. Sebagai contoh adalah alasan ekonomi/keuangan, kondisi keluarga kedua belah pihak, KDRT, kepuasan seks, perselingkuhan dan masih banyak lagi yang lainnya. Akan tetapi, semua alasan tersebut pada akhirnya akan sampai pada sebuah sikap "ketidaksetiaan". Jika telah sampai pada fase ini, potensi keributan yang pada gilirannya akan bermuara pada keretakan rumah tangga maka perceraian dapat saja terjadi.

Janji suci yang diucapkan dalam pernikahan di hadapan Allah dan manusia memberikan sebuah 
isyarat yang kuat bahwa keduanya akan tetap setia menjalani pernikahan tersebut, sampai maut (kematian jasmani) memisahkan mereka. Akan tetapi, apa jadinya jikalau di tengah jalan terjadi perceraian? Berdasarkan pengalaman empiris memperlihatkan bahwa potensi perceraian sangat terbuka karena ketidaksetiaan. Ada beberapa yang nota bene beragama Kristen yang pada awal-awal pernikahan mereka kelihatan sangat romantis. Namun, di luar dugaan bahwa pada akhirnya, salah satu dari mereka mengajukan perceraian dengan alasan klasik yaitu ketidakcocokan antar satu terhadap lainnya. Apakah alasan yang sesederhana itu sehingga sampai pada ancaman perceraian? Ternyata tidak demikian. Sekalipun pada bagian ini peneliti tidak ingin membahas pernikahan dan perceraian, sebab bagian tersebut memiliki ruang lingkup khusus untuk diuraikan. Namun, penekanan yang ingin ditegaskan di sini ialah sikap ketidaksetiaan terhadap isi perjanjian. Atau, dengan kata lain bahwa telah terjadi pengingkaran/pengkhianatan terhadap perjanjian yang telah diikat bersama kedua belah pihak. Ini dapat dikategorikan sebagai salah satu indikator tindakan ketidaktaatan sehingga menimbulkan kecemburuan yang hebat. Dalam konteks ini, pada satu sisi ada pihak yang mengkhianati dan pada sisi lain, ada juga pihak yang dikhianati atau disakiti. Karena itu, identitas kecemburuan dan yang melatarbelakanginya merupakan prinsip penting untuk dipelajari dan dipahami secara benar.

Kadar kecemburuan TUHAN tentu berbeda dengan kadar kecemburuan manusia apalagi berhubungan dengan relasi antar Pencipta dan yang dicipta. Namun, faktor yang paling penting adalah bagaimana kesetiaan itu mesti dimaknai dengan benar. Dengan demikian, TUHAN sangat cemburu apabila manusia selaku ciptaan-Nya tidak hidup dalam kesetiaan penuh terhadap konten perjanjian dengan Allah. Ketundukan dan kesetiaan mesti dihadirkan bersama sebagai pengejawantahan dari prinsip takut akan TUHAN.

\section{Ketidaktaatan terhadap Perjanjian Berkat Allah}

Fakta Alkitab membuktikan bahwa Allah telah mengingatkan umat-Nya jauh sebelumnya agar sungguh-sungguh taat dan setia kepada-Nya termasuk mentaati Perjanjian Berkat-Nya. Hal inilah yang ditekankan di dalam Keluaran 20. Konten Perintah Pertama (First Stipulation) dituangkan di dalam ayat 3-4 tentang keutamaan Allah yang harus dijunjung, ditaati dengan sikap setia. Dalam Tafsiran Wycliffe dijelaskan bahwa perintah ini bukan sekedar pernyataan monoteisme atau ketunggalan Allah. Perintah ini melarang penyembahan atau penghormatan kepada sesuatu yang lain lebih daripada kepada Allah baik dalam pikiran, ucapan, maupun perbuatan "sehingga Ia yang lebih utama dalam segala sesuatu" (Pfeiffer \& Harrison, 1962, p. 202). Sebagai Yang Utama dalam ikatan Perjanjian Berkat dengan Israel, ada tuntutan bagi Israel untuk taat dan setia, terhadap TUHAN dan Perjanjian yang telah diikat-Nya dengan mereka.

Perlu dipahami bahwa indikator penyebab kecemburuan Allah ialah pengingkaran terhadap Perjanjian dengan TUHAN, bersikap tidak taat dan tidak setia, serta memberontak terhadap-Nya. Realitanya Israel sering mengingkari Perjanjian dengan Allah. Israel bahkan tidak mempedulikan Allah sebagai Pembebas dari perhambaan dan mengabaikan-Nya melalui ketidak taatan dan ketidak setiaan mereka. Maksudnya, Israel tidak lagi mencari TUHAN dalam sikap taat dan setia yang benar dan yang intens dengan-Nya. Israel lebih banyak menyibukkan diri dengan hal-hal yang bersifat fana, sementara, dan tidak lagi menjadikan Allah sebagai yang utama dan dengan sendirinya merusak keintimannya dengan TUHAN. Miris jika umat kepunyaan-Nya tidak lagi bersikap taat dan setia kepada TUHAN-nya.

Kecemburuan Allah dalam konteks ketidak taatan dan ketidak setiaan Israel juga disebabkan oleh karena mereka tidak hidup dalam kerendahan hati dengan membelakangi dan menolak menyembah hanya kepada TUHAN Allah saja. Inilah juga yang diingatkan oleh Allah kepada umat-Nya tatkala ber- 
buat kesalahan dengan ketidaktaatan terhadap Perjanjian dengan TUHAN. Dalam upaya mendapatkan imbal atas ketaatan dan kesetiaan Israel terhadap Perjanjian Berkat TUHAN. TUHAN Allah menyatakan persyaratan tegas, "dan umat-Nya, yang atasnya nama-Nya disebut, merendahkan diri, berdoa dan mencari wajah Allah, maka Allah mendengar, mengampuni dosa, dan memulihkan mereka ... (II Taw. 7:14). Karena itu, kecemburuan itu dapat terjadi jika Israel tidak taat dan tidak setia kepada TUHAN dengan mengikari Perjanjian dengan-Nya.

Perlu disadari bahwa ketaatan dan kesetiaan kepada TUHAN dapat diidentifikasi dalam hubungan Israel dengan TUHAN, melalui doa. Doa merupakan alat atau sarana efektif untuk dapat berkomunikasi dengan Allah, guna mengungkapkan ketaatan dan kesetiaan kepada-Nya. Demikian juga dengan membaca Alkitab yang menjadi media untuk mengetahui isi hati TUHAN bagi hidup umat-Nya. Melalui pembacaan dan perenungan Firman Israel sebagai umat akan mengetahui tujuan dan cara-cara Allah menuntun mereka yang kadang di luar dari daya nalar dan logika manusia.

Israel dan Gereja sebagai umat Allah perlu mengupayakan dan mewujudkan komunikasi yang baik dan benar (dua arah) dengan TUHAN, melalui doa, serta membaca Alkitab, sebagai bagian dari upaya mewujudkan ketaatan dan kesetiaan kepadaNya. TUHAN Allah menyiapkan sarana atau media komunikasi yang tidak memerlukan pulsa atau uang untuk dapat menghampiri-Nya, bahkan kecepatan komunikasi tersebut tidak bergantung pada kecepatan jaringan atau kecepatan akses internet (MPMBS) dalam memproses pengiriman pesan tersebut seperti biasa ditemukan dalam media komunikasi zaman sekarang. Sayangnya, manusia tidak menggunakan dan menjadikan doa dan membaca Alkitab sebagai sarana membangun ketaatan dan kesetiaan terhadap TUHAN, bahkan berelasi dalam keintiman denganNya. Dapat dipastikan bahwa inilah salah satu penyebab yang memicu kecemburuan TUHAN, akibat ketiadaktaatan dan ketidaksetiaan umat-Nya.
Anjaly dan Naryoso (2016) mengemukakan sebuah pandangan atau prinsip penting yang mengindikasikan betapa pentingnya komunikasi dalam sebuah hubungan. Menurut mereka bahwa

untuk mengembangkan dan memelihara hubungan, pasangan tersebut perlu membangun komunikasi antar pribadi yang dilandasi sikap saling percaya (trust), sikap suportif, dan terbuka. Lebih dari itu, tetap berusaha untuk memberikan kepercayaan yang masing-masing pihak tidak menunjukkan perilaku defensif tetapi menunjukkan perilaku yang menerima, jujur, dan berempati. (Anjaly \& Naryoso, 2016).

Jika komunikasi sebagai napas dalam sebuah hubungan tetap dibangun, dijaga serta dikembangkan, rasanya peluang untuk taat dan setia dapat diminimalisasi dengan baik. Hal ini dapat dirasakan selama Umat Allah dapat mengembangkan komunikasi yang baik degan TUHAN, yang di dalamnya mengandung prinsip trust, sikap support, serta terbuka sehingga kesempatan untuk mengabaikan Allah seperti penjelasan pada bagian di atas sama sekali tidak mendapat ruang dalam hubungan Umat dan TUHAN-nya.

Bagi Gereja atau umat Allah masa kini, Peneliti tidak perlu menguraikan konsep doa dan upaya membaca Alkitab dalam tulisan ini, namun penekanan tentang doa dan membaca Alkitab sebagai bagian dari tanda ketaatan dan kesetiaan kepada Allah menjadi tuntuan utama atau faktor utama menaati Perjanjian Berkat TUHAN.

Telah diuraiakan bahwa Kecemburuan Allah terjadi karena Israel tidak taat dan tidak setia kepada TUHAN Allah dengan tidak terikat kepada-Nya dalam doa dan sabda-Nya. Ibarat sepasang kekasih yang sedang membangun hubungan kasih, sang pria begitu mengasihi pacarnya, namun pada sisi lain sang wanita tersebut mengabaikan pacarnya dengan jalan membangun hubungan atau relasi dengan orang lain (pihak ketiga) alias tidak setia; yang berakibat pada rusaknya hubungan tersebut. Demikian juga TUHAN Allah, Ia tidak menghendaki ketidaktaatan dan ketidaksetiaan umat-Nya kepada diri-Nya, bahkan Ia tidak rela atau sudi jika hubungan istimewa atau privilese yang telah terbangun jauh sebelumnya, kini menjadi rusak kare- 
na adanya "penyembahan kepada ilah lain" yang dibiarkan mengganggu dalam relasi tersebut.

\section{Pemberontakan terhadap TUHAN}

Kecemburuan Allah juga terjadi karena ketidakpuasan dalam kualitas relasional Israel sebagai ciptaan-Nya dengan Allah sebagai Pembebas. Allah menghendaki yang terbaik dan sempurna sebagaimana sifat khas-Nya sebagai Allah yang Mahasempurna, Mahaadil dan Mahasetia. Kualitas relasi yang buruk juga dapat digambarkan sebagai bentuk perzinahan umat Israel yang menggambarkan adanya pemberontakan terhadap TUHAN, yang berakibat adanya penghukuman Allah. Hal ini dapat ditemukan dalam Keluaran 20:14, di mana pada sisi lain, dampak atau konsekuensi logis dari tindakan penghukuman terhadap pemberontakan Israel ini dapat dijumpai juga dalam Ulangan 22:22.

Berkenaan dengan terminologi perzinahan ini, Sabdono (2018) memaparkan gagasannya dengan menyatakan bahwa perzinahan dipandang sebagai suatu tindakan di mana terjadi hubungan kelamin antara laki-laki dan perempuan yang belum terikat oleh sebuah ikatan pernikahan secara yuridis maupun secara adat. Perzinahan meliputi hubungan kelamin antara laki-laki dan perempuan yang masing-masing atau salah satu terikat dengan ikatan pernikahan dengan pasangan lain (Sabdono, 2018). Jadi, dapatlah disimpulkan bahwa perzinahan Israel pada bagian ini, memberikan sebuah gambaran bahwa mereka merasa tidak puas dan berusaha untuk mencari sesuatu yang kemudian diharapkan membuatnya terpuaskan, dengan menyembah ilah lain. Dengan demikian, praktik Israel yang menyembah ilah lain, dianggap sebagai perzinahan, merupakan tindakan pelarian karena merasa tidak puas untuk mentaati dan bersikap setia terhadap TUHAN. Jadi, jika dikorelasikan dengan konteks "kecemburuan Allah" maka Israel yang melakukan penyembahan kepada ilah lain disebut sebagai perzinahan yang ditentang TUHAN. Hubungan khusus antara Israel dengan allah lain dan ini dilakukan di luar ikatan spiritual antara Allah dengan
Umat-Nya yang dianggap sebagai sebuah tindakan ilegal di mata TUHAN. Israel dengan sendirinya membangkitkan kecemburuan Allah dengan jalan melakukan perzinahan dengan allah lain sebagai bagian dari ungkapan ketidakpuasan, ketidaksetiaan dan ketidaktaatan serta ketidakhormatan mereka kepada Allah yang hidup yang telah membuktikan kesetiaan-Nya sepanjang sejarah pemeliharaan-Nya, sehingga mereka pada akhirnya terhukum.

Pasca kematian Yosua (Yos. 24:29-30), bangsa Israel hidup dalam penyembahan kepada berhala bangsa-bangsa lain. Alkitab mencatat dalam Hakim-hakim pasal 2:6-23 hingga pasal 17:1-13, di mana umat Israel hidup dalam penyembahan berhala. Hakim lepas hakim, namun cara hidup mereka tidak pernah mengalami perubahan yang permanen dan hanya bersifat temporari saja. Hal ini terbukti dalam proses sejarah. Sebut saja Debora dan Barak, Gideon, Yefta bahkan Simson yang gagah perkasa, semua ini membuktikan kepedulian Allah bagi Israel. Namun realitanya setelah mereka tua dan mati, orang Israel kembali pada tabiat lama yakni hidup dalam perzinahan kepada allah lain dan menyakiti hati Allah. Tentu, hal ini sangat melukai hati Allah. Mereka hidup dalam penyembahan terhadap ilah-ilah atau baal-baal yang sesungguhnya merupakan ciptakan mereka sendiri.

Sejalan dengan kitab Hakim-Hakim, dalam kitab Yehezkiel secara khusus pasal 16 pun memberikan peneguhan kepada para pembaca bahwa Yerusalem hidup sebagai perempuan sundal. Yerusalem hidup dalam ketidaksetiaan dan ketidakpuasan terhadap Allah.

Jika membawa kondisi ini dalam konteks hari ini, maka tindakan perzinahan apa saja yang mengindikasikan atau mengimplikasikan umat TUHAN telah dan sedang hidup dalam perzinahan atau telah membelakangi Allah dengan mengganti fokus penyembahan terhadap-Nya? Jawabannya, seperti pada uraian sebelumnya, Idleman (2014) telah memberikan beberapa indikasi tersebut, bahwa ternyata umat TUHAN telah membelakangi Allah, mereka telah 
berzinah, atau dengan kata lain, Israel telah mengalihkan fokus utamanya dari Allah pada pihak ketiga, yakni: allah seks, allah sains/allah pengetahuan, allah uang, allah hiburan/hobi, allah kesuksesan/allah prestasi, allah makanan. Tentu banyak hal lain lagi yang searah dan seirama; termasuk media sosial dan kecanggihan teknologi zaman sekarang (Idleman, 2014).

Pada dasarnya semua indikator yang telah dibahas sangat berguna bila dilakukan, digunakan, atau diterapkan sesuai dengan kebutuhan dalam konteks kekinian. Namun, tindakan-tindakan ini pada akhirnya akan terhitung sebagai sebuah sikap perzinahan yang memiliki implikasi membelakangi Allah dengan mengganti fokus penyembahan terhadap-Nya, ini yang menjadi persoalan. Atau dengan kata lain, mengandung motif serta ditunggangi oleh muatan yang sangat menyimpang, yakni sikap ketidakpuasan manusia terhadap Allah, dengan alasan yang tidak jelas dan sebenarnya hal tersebut adalah salah. Dan inilah perzinahan di hadapan Allah, yang menjadikan-Nya cemburu karena tindakan manusia tersebut.

\section{Perspektif Teomorfistik}

\section{Allah Sang Pencemburu}

Setelah uraian pada bagian awal mengenai ketidaksetiaan manusia yang dimulai sejak masa Perjanjian Lama, maka seyogianya umat Allah perlu juga mencermati sikap Allah terhadap manusia sebagai bagian dari keseriusan-Nya dalam menyikapi ketidaktaatan dan ketidaksetiaan tersebut. Dalam kedaulatan-Nya, umat Allah menemukan sifat lain dari Allah yang ditunjukannya bagi umat-Nya, yaitu Kemahaadilan dan Kemahasetiaan-Nya. Sejak awal, secara gamblang Allah telah menyatakan diri-Nya terhadap Israel, bahwa Ia adalah Allah yang cemburu (Kel. 20:5, 34:14; Ul. 4:24). Pada satu sisi, kecemburuan Allah terhadap penyembahan berhala menandaskan bahwa Ia adalah Allah yang tidak dapat direpresentasikan dalam bentuk apapun, sebab secara ti- dak langsung kecemburuan Allah ini mendeklarasikan bahwa Ia adalah Allah yang kudus, Mahaadil dan Mahasetia, yang harus ditaati oleh umat-Nya (Wauran, 2015). Perspektif teomorfistik menegaskan bahwa TUHAN Allah Yang Mahaadil dan Mahasetia yang telah mengikat Penjanjian Berkat dengan Israel (Kel. 20:1-17) menyertakan penghukuman atas pengingkaran terhadap kovenan-Nya. Dengan demikian, pelanggaran Israel yang mengingkari Kovenan dengan TUHAN Allah melalui ketidaktaatan dan ketidaksetiaan mereka menjelaskan bahwa mereka dengan sendirinya terhukum, sebagai implikasi kecemburuan Allah.

Penggunaan kata cemburu pada (Kel. 20:5) P Panna, yang berarti Jealous - Cemburu. Kata Qanna berbentuk adjective masculine singular absolute. Vine, Unger, dan White (1996) menjelaskan bahwa “... kata tersebut merujuk langsung pada atribut keadilan dan kekudusan TUHAN, karena Dia adalah satu-satunya objek penyembahan manusia dan tidak menoleransi perbuatan dosa manusia."

Di sisi lain, kata cemburu dalam bahasa Yunani - septuaginta merujuk ayat yang sama, dite-

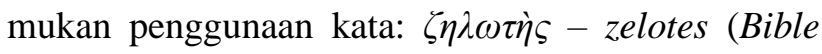
Works 9, n.d.), yang berarti zealot (orang Fanatik). Selanjutnya Idleman (2014) menjelaskan bahwa di dalam Alkitab kata jealous (cemburu) dan zealous (tekun, giat) secara mendasar saling dapat dipertukarkan dalam teks aslinya, keduanya memiliki kata yang sama. Sedangkan di dalam bahasa Inggris, keduanya hampir senada, karena memang berasal dari akar kata yang sama di dalam bahasa Yunani. Karena itu, kata zeal sebagai antusiasme yang penuh semangat. Jadi, bagi Idelman, ide ini menangkap alasan mengapa Allah sangatlah posesif pada umat-Nya: sebab Ia, sebagaimana yang dikatakan-Nya, adalah api gairah yang menghanguskan (Ul. 4:24) (Idleman, 2014).

Itu artinya dalam keadilan dan kekudusan Allah, Ia juga adalah Allah yang Fanatik. Fanatik dalam artian, jika manusia selaku umat-Nya menyimpang atau mendua dari penyembahan yang semes- 
tinya diarahkan terhadap-Nya. Atau dengan kata lain, hanya Dia satu-satunya yang patut disembah dan tidak ada ruang bagi allah lain untuk disembah. Inilah bangunan teologi zelotes/zealot yang sejati.

Sikap fanatik ini diibaratkan seperti suporter dari sebuah kesebelasan sepak bola yang mati-matian menjagokan, mengagumi serta mengidolakan salah satu klub sepak bola kesayangannya, dan mereka rela menjadi "taruhan" demi klub yang dibanggakan tersebut. Akibat dari sikap fanatis ini dapat melahirkan permusuhan, kerusuhan, pengrusakkan, dan bahkan kematian seperti banyak terjadi. Contoh, klub sepak bola Persija Jakarta (Jack Mania, yang lebih akrab dipanggil dengan Macan Kemayoran). Mereka berusaha mati-matian membela Persija Jakarta tatkala bertanding melawan klub lain dalam liga Premier Indonesia, apalagi saat bertemu dengan Persib Bandung, sebagai musuh bebuyutan. Fanatisme suporter yang sangat kental terlihat saat terjadi kerusuhan pasca kekalahan, mereka habis-habisan membela klub tersebut walaupun ada yang harus mati (memakan korban dari kedua belah pihak).

Penggambaran di atas menunjukkan fanatisme yang juga memiliki bobot tatkala dihubungkan dengan TUHAN. Manusia selaku umat Allah perlunya sikap fanatik-positif seperti termuat dalam kata $\zeta \eta \lambda \omega \tau \dot{\zeta} \varsigma-z e l o t e s$ dalam mengiring TUHAN. Jangan sampai dalam perjalanan hidup, kemudian menyimpang dari iman. Atau dengan kata lain, hidup dalam ketidaksetiaan di hadapan TUHAN, yang pada ujungnya membuat Allah cemburu karena umat-Nya telah menyelingkuhi Dia melalui sikap yang ditunjukkan yakni, tindakan mendua hati - Kel. 20:35. Fanatik di sini tidak mengindikasikan sebuah tindakan ketidakpedulian terhadap agama lain atau aliran lain dalam organisasi gereja, ataupun sebuah agama. Bukan konteks seperti itu.

Topik ini dapat menimbulkan pertanyaan yang tak berujung, mengapa Allah harus/perlu cemburu terhadap manusia? Bukankah segala sesuatu datangnya dari Dia? Lagipula segala hal yang ada di muka bumi ini dan seluruh tata surya merupakan hasil
ciptaan-Nya, buatan tangan-Nya? Untuk apa Allah harus bersusah-susah serta "berlelah hati" untuk mencemburui manusia yang notabene merupakan ciptaan-Nya yang tidak lebih dari seonggok tanah liat? Inilah pertanyaan sekaligus pernyataan yang wajib digumuli untuk menemukan jawaban dari sifat Allah tersebut sebagaimana telah dijabarkan.

Idleman (2014) mengatakan lagi bahwa dalam Alkitab ditemukan banyak bentuk penggunaan nama Allah menurut karakter kualitas-Nya. Dia adalah "Raja di atas segala Raja", "Sang Pembebas", Sang Pemelihara", "Sang Penyembuh", dan "Sang Penebus". Daftar nama Allah ini akan semakin banyak dan lebih panjang jika diinventarisir menurut atribut-Nya. Namun, dari semua nama Allah, ada satu nama yang tampaknya sudah jarang digunakan bagiNya, yakni Allah yang cemburu dalam Keluaran 34:14 (Idleman, 2014).

Lebih lanjut, Idleman menjelaskan bahwa rupanya Allah begitu mencemburui manusia, umatNya. Bukan karena Ia merasa disaingi, tidak! Melainkan lebih dari itu! Allah begitu mengasihi umatNya, pembuktian bahwa Allah begitu mengasihi, diwujud nyatakan-Nya saat harus menanggung dosa umat-Nya, melewati via dolorosa, dan klimaksnya saat Ia terpaku di kayu salib. Inilah sintesis dari pandangan-pandangan yang keliru tentang kecemburuan Allah! Selanjutnya, ada pernyataan menarik dari Idleman sehubungan dengan bagian ini, bahwa "Ia terlalu mengasihi Anda sampai-sampai Ia tidak rela membagi Anda dengan yang lain" (Idleman, 2014).

\section{Menimbulkan Penghukuman TUHAN}

Jika memperhatikan teks Ul. 4:24, 25 dan 28, maka di sana ditemukan ekspresi terdalam sebagai ungkapan hati Allah. Ayat 24, "TUHAN diibaratkan seperti api yang menghanguskan". Ayat 25 "jika mereka berlaku busuk dengan membuat patung yang menyerupai apa pun dan hal ini menimbulkan sakit hati-Nya". Melalui ayat 26 ditemukan perasaan Allah yang luar biasa yaitu, "beribadah kepada allah buatan 
tangan manusia, yakni kayu dan batu yang tidak dapat melihat, tidak dapat mendengar, tidak dapat makan dan tidak dapat mencium". Inilah gagasan yang jarang disentuh oleh beberapa penulis lain berkenaan dengan sifat khas Allah.

Luapan hati Allah ini, jika diamati sebenarnya mewakili sakit hati-Nya (ayat 25). Allah yang layak menerima penyembahan dan pengagungan, justru diingkari dengan tidak taat dan tidak setia, sebagai tanda pemberontakan terhadap TUHAN. Pemahaman ini sebenarnya linear dengan konsep pernikahan kudus dalam kekristenan, di mana pernikahan monogami yang mengusung kesetiaan sebagai ciri utama, harus senantiasa dijunjung tinggi sebagai bagian dari produk utama dalam pernikahan yang kudus. Tapi bagaimana seandainya, kesetiaan itu tidak lagi dijumpai dan ditemukan dalam pernikahan Kristen, yang menjelaskan produk utama dari pernikahan monogami, dan sebaliknya justru melahirkan atau menimbulkan sakit hati? (Winarto, 2020) Ingat, Ia adalah pribadi! Jika Ia tidak dihormati, tidak ditaati dengan tindakan yang dibuat oleh umat-Nya, dalam hal ini Israel yang hidup dalam penyembahan kepada allah lain, maka ada konsekuensi logis yang akan diterima dan sangat beralasan jika Allah cemburu dengan tindakan tersebut dan mendatangkan penghukuman (ayat 24 band. Kel. 20:5). Karena itu, Darmaputera (2005, p. 33) menegaskan bahwa "yang mutlak itu bukan cuma ada; tetapi juga bahwa yang mutlak itu cuma satu. Cuma Dia ... Bila yang mutlak itu "Cuma Dia" maka konsekuensinya adalah semua yang lain - apa pun itu, kecuali Dia - tidak mutlak." Pernyataan ini memang sangat tegas dan bersifat fanatis-positif dalam iman dan keyakinan kepada TUHAN.

Moo sebagaimana dipaparkan dalam tulisan Brake (2016) menjelaskan bahwa keesaan, kecemburuan, dan kasih karunia TUHAN adalah tiga aspek penting dari karakter TUHAN yang diungkapkan dalam surat ini. Keesaan TUHAN mengacu pada keteguhan TUHAN yaitu sebuah karakteristik yang harus tercermin dalam kehidupan orang percaya juga.
Kecemburuan TUHAN berhubungan dengan gagasan bahwa umat-Nya harus dengan sepenuh hati taat dan setia mengabdi kepada-Nya. Sementara TUHAN menuntut ketaatan dan kesetiaan yang taat dari orangorang percaya, Dia juga memberi kasih karunia kepada mereka yang sebelumnya ingin merendahkan diri (Brake, 2016). Menurut Brake (2016) gagasan Moo, tentang keesaan, kecemburuan, dan rahmat TUHAN adalah tiga aspek penting dari pribadi Allah yang tidak dapat dilepas-pisahkan dari Allah sendiri. Perihal kecemburuan Allah, sebenarnya terkait dengan gagasan bahwa umat-Nya harus berbakti total dan sepenuh hati kepada Allah yang hidup, tetapi bagaimana jika manusia justru menimbulkan sakit hati Allah?

Melalui ayat 25 ada sebuah pernyataan

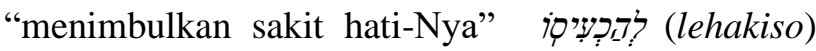
dari kata dasar כּ (kaas) yang bermakna to be angry, vexed, to vex - menjadi marah, kesal, untuk menyusahkan (verb, hifil, infinitif - kata kerja infinitif, tanpa batas sebab tidak dibatasi oleh subjek. Hifil, menyatakan suatu arti kausatif - membuat jadi).

Menurut catatan Wicliffe, ayat 24-26 termasuk ayat 25 ini yang sering diabaikan oleh banyak penafsir modern sebagai peninggalan aneh berbau dongeng dan takhyul ini adalah sebenarnya suatu ilustrasi tentang sebuah hukum rohani yang ada di sepanjang Alkitab dan sejarah yaitu orang yang bertugas memberitakan kehendak Allah kepada orang lain, harus terlebih dahulu menaati kehendak Allah yang telah dinyatakan-Nya (Pfeiffer \& Harrison,

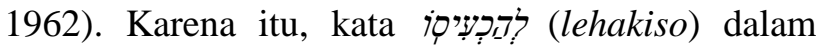
konteks ini memberikan sebuah gambaran bahwa saat manusia menyembah allah lain, maka secara tidak langsung membuat TUHAN menjadi marah; membuat TUHAN menjadi kesal dan tentunya menyusahkan hati TUHAN Allah sendiri, sebab ciptaan-Nya telah melukai hati-Nya dengan menyembah allah lain (Kel. 20:5 \& Ul. 4:25). Jika dikomparasikan dengan Terjemahan Baru (TB) - LAI (menimbulkan sakit hati-Nya) yang dilihat dari kasus infinitif, maka kita tidak akan tahu sesungguhnya sejauh mana atau 
sampai kapan batas sakit hati TUHAN Allah terhadap manusia yang telah menimbulkan sakit hati-Nya atau melukai hati TUHAN Allah tersebut.

\section{KESIMPULAN}

Sesungguhnya TUHAN Allah dan atributNya yang kekal tidak dapat dipahami secara tuntas dengan daya nalar manusia yang sangat terbatas. Diperlukan kerendahan hati dan keberserahan total pada kedaulatan kehendak-Nya. Apa yang dinyatakan telah cukup bagi umat-Nya dan hanya dibutuhkan kesetiaan dan ketaatan.

Artikel berkenaan dengan Allah pencemburu ini adalah salah satu dari sekian banyak artikel yang membahas tentang atribut Allah yang termuat dalam Perjanjian Lama secara khusus dalam kitab Keluaran. Sebagaimana diketahui bahwa kitab Keluaran adalah kitab yang membahas banyak hal tentang kisah-kisah bangsa Israel/umat-Nya ketika berhadapan dengan tantangan di sepanjang perjalanan hidup mereka. Selain berhadapan dengan tantangan, tetapi mereka juga berhadapan dengan sifat-sifat khas yang diperlihat-

\section{DAFTAR RUJUKAN}

Anjaly, A. P., \& Naryoso, A. (2016). Komunikasi Antar Pribadi Pada Pasangan Romantis Pasca Perselingkuhan. Interaksi Online, 4(2), 1-11. Retrieved from https://ejournal3.undip.ac.id/index.php/interaks i-online/article/view/11273

Berkhof, L. (1993). Teologi Sistematika 1-Doktrin Allah. Jakarta: Lembaga Reformed Injili Indonesia.

Bible Works 9. (n.d.).

Brake, L. J. (2016). Little Book, Big Waves: The Epistle of James and Global Stewardship in Bioethics. Jurnal Jaffray, 14(1), 131-154. https://doi.org/10.25278/jj71.v14i1.196

Brehm, S. (1992). Intimate relationships. New York: McGraw-Hill.

Budijanto, B. (1995). TORAH dalam Hidup Bangsa Israel. Yogjakarta: Yayasan Andi. kan oleh Allah melalui diri-Nya sendiri. Kehadiran Dasatitah mengubahkan dan membentuk paradigma mereka tentang relasi mereka dengan TUHAN dan sesama.

Seperti telah dijelaskan sebelumnya bahwa TUHAN Allah sangat cemburu karena tindakan ketidaksetiaan yang dilakukan dengan sengaja oleh umat kepunyaan-Nya sendiri dengan cara menyembah allah lain. Dengan sikap kecemburuan ini juga memperjelas gagasan dan konsep tentang monoteisme. Rasa cemburu Allah menggambarkan kekudusan dan relasi eksklusivitas antara Allah dengan umat-Nya. Fakta biblis-teologis menjelaskan bahwa yang menjadi latar kecemburuan Allah tersebut ialah: adanya janji yang diingkari (dikhianati) dengan tidak setia; kemudian adanya sebuah sikap diduakan dan yang terakhir ialah adanya sikap ketidakpuasan yang dapat dikategorikan sebagai bentuk perzinahan dengan allah-allah lain. Allah layak cemburu karena pelanggaran terhadap covenan-Nya yang kekal yang menjelaskan bahwa Allah sangat mengasihi manusia, umat kepunyaan-Nya.

Darmaputera, E. (2005). Sepuluh Perintah ALLAH: Museumkan Saja. Jakarta: Gloria Graffa.

Duma, U. (2009). Jealousy and Compersion in Close Relationship. Germany: Deutschen Nationalbibliografie.

Gaebelein, F. E., Harris, R. L., \& Kaiser Jr., W. C. (1990). The Expositor's Bible Commentary Vol. 2: Genesis, Exodus, Leviticus, Numbers (F. E. Gaebelein, Ed.). Grand Rapids, Michigan: Zondervan Publishing House.

Idleman, K. (2014). Gods at war. Jawa Timur: Literatur Perkantas.

Indonesia, T. P. K. B. B. (2014). Kamus Besar Bahasa Indonesia. Jakarta: Gramedia Pustaka Umum.

Johnson, E. A. (1984). The Incomprehensibility of God and the Image of God Male and Female. Theological Studies, 45(3), 441-465. 
https://doi.org/10.1177/004056398404500302

Kusnandar, C. (2015). Sepuluh Firman Tuhan Bagian Pertama: Kasih Terhadap Allah Dalam Tinjauan Etika Kristen. Majalah Ilmiah Methoda, 5(1), 54-59.

Lestari, R. (2015). MENJADI ATEIS: Sebuah Studi Naratif Mengenai Proses Pengambilan Keputusan (Universitas Pendidikan Indonesia). Universitas Pendidikan Indonesia, Bandung. Retrieved from http://repository.upi.edu

Ludji, B. (2009). Pemahaman Dasar Perjanjian Lama. Jakarta: Bina Media Informasi.

Packer, J. I. (2008). Knowing God, Tuntunan Praktis Untuk Mengenal Allah. Yogyakarta: Penerbit ANDI.

Pfeiffer, C. F., \& Harrison, E. F. (1962). The Wycliffe Bible Commentary (Vol. 1). Chicago: The Moody Bible Institute of Chicago.

Sabdono, E. (2018). Perceraian - Hakikat Perkawinan Menurut Alkitab. Jakarta: Rehobot Literature.

Stamps, D. C. (1996). Alkitab Penuntun Hidup
Berkelimpahan (2 st). Malang: Gandum Mas.

Surbakti, E. B. (2009). Kenalilah Anak Remaja Anda. Jakarta: Elex Media Komputindo.

Suseno, F. M. (2006). Menalar Tuhan. Yogyakarta: Kanisius.

Tomatala, Y. (2003). Teologi Misi, Suatu Dogmatika Tentang Misi, Penginjilan dan Pertumbuhan Gereja. Jakarta: YT Leadership Foundation.

Vine, W. E., Unger, M. F., \& White, W. (1996). Vine's Expository Dictionary of Biblical Words. Nashville: T. Nelson.

Wauran, Q. C. (2015). Kajian Biblika Kecemburuan Allah Terhadap Penyembahan Berhala Berdasarkan Keluaran 20:4-6. Jurnal Jaffray, 13(2), 249-284. https://doi.org/10.25278/jj71.v13i2.180

Winarto, A. (2020). "Kau Bukan Seperti Yang Dulu Lagi': Sebuah Refleksi Teologis-Etis Perceraian. SOLA GRATIA: Jurnal Teologi Biblika Dan Praktika, 1(1), 65-73. https://doi.org/10.47596/solagratia.v1i1.2 